\title{
境界要素法を活用した航空機概念設計法について*1 \\ 一大学における設計教育への適用一 \\ Studies on Aircraft Conceptual Design Incorporating Boundary Element Method for University Design Education
}

\author{
河 井 俊 $之^{* 2, * 3} \cdot$ 李 家 賢 - ${ }^{* 4}$ \\ Toshiyuki KaWAI and Kenichi RINOIE
}

Key Words : Aircraft Conceptual Design, Boundary Element Method, Single Engine Light Aircraft

\begin{abstract}
Aircraft conceptual design method currently used for the university design education mainly utilises empirical values based on the statistical database to determine the main design parameters. Therefore, it is often difficult for students to understand the effects of aerodynamic parameters such as a wing aspect ratio and a taper ratio during the design process. In this paper, a conceptual design method that incorporates a boundary element method is discussed so that aerodynamic characteristic estimations are possible and that the students can easily comprehend the effects of aerodynamic parameters while designing the airplane. A single engine light airplane has been designed by the present conceptual design method. The results obtained by the present method and those by the conventional method are compared and discussed.
\end{abstract}

\section{1. 序論}

航空機の設計・開発は，市場調査から始まり，概念設計・ 初期設計・詳細設計と進んで行き，製造と飛行試験が行わ れた後に，量産のプロセスへとつながる1)．

概念設計では , 主に統計データを基にして機体离倠陸重量 , エンジン出力, 翼面積等の初期値を算出する, いわゆる “Sizing”が行われ, 設計要求を満たす機体形状が決定される. 次 の初期設計では, 概念設計の結果を基に, 風洞実験や CFD によって，詳細な空力特性が調べられる．ここでの結果は， 概念設計段階で統計データ等から仮定された値と比較され， 妥当でない場合には，機体形状に修正か加えられたり，ある いはSizing の作業が繰り返されることになる . 空力設計に 続いて構造設計が行われ，最終的な機体形状が決定される．

このように, 航空機設計においては, 機体性能や炎の空 力特性を正確に推算していくことは非常に重要である.設 計・開発においては, コス卜低減や開発期間の短縮なども 同時に求められており，概念設計や初期設計での高精度化， 効率化が必要とされている2).

ところで, 従来の概念設計法ては, DATCOM ${ }^{3)} や \mathrm{ESDU}^{4)}$ などの統計データに頼るところが大きい．実際に，これら のデータは大変重要であり, 航空機設計に不可欠である. 風洞試験を行うには, 風洞試験模型が必要であり, 機体形

\footnotetext{
*1 C 2003 日本航空宇宙学会

平成 13 年 10 月 30 日, 第 39 回飛行機シンポジウムにて講演。

平成 14 年 11 月 21 日原稿受理

*2 東京大学大学院

*3 現 三菱重工業 (株)

*4 東京大学大学院工学系研究科航空宇宙工学専攻
}

状がある程度決まる前から試験を行うことには, 時間もコ ストもかかることになる．また, Navier-Stokes 方程式を 用いた数値解析手法 (CFD) についても，現状では計算 時間や手間がかかり，機体形状を自由に変化させてパラメ トリック・スタディを行うことには困難を伴う．乥こでも う少し簡便な空力設計法を概念設計と同時に並行して行う ことで, 設計の精度を上げ, 効率化を図ることが設計現場 で行われている.

一方, 大学, 大学院における航空機設計教育の現状につ いて考えてみる. 現在世界で広く使用されている航空機設 計の教科書に文献 5,6) などがある.これらの文献を用い ると学生が各種形態の航空機に関して概念設計を行うこと ができる．ただし，これらの文献の方法は統計データを多 用しているため, 例えば主翼のアスペクト比やテーパー比 の変化すなわち空力特性の変化が機体諸元に及ぼす影響に ついて，たとえ数値として結果が得られたとしても，初め て航空機設計を試みる学生にとっては, 光の物理的意味を 理解することに困難を感じることがあげられる．更には文 献 5,6) 等の方法では，機体の概略を決定した後に詳細な 空力計算を行い, 空気力学的パラメータの影響を見るとい う方法がとられており, 最終的に設計された機体に, 空力 パラメータの影響が含まれることになる．しかしながら教 育上の時間的制約により，概念設計，初期設計と学生が段 階を踏んで設計をすすめることは, ほとんど不可能なのが 現状である.光こで, このような従来からの教育用航空機 設計法とは別の方法, すなわち上述した空力特性の推算も 同時に並行して概念設計を行う方法を教育カリキュラム上 の時間的制約の範囲内で試みることを考える .これによっ 
て, 概念設計段階でも空力特性变化の物理的意味を把握す ることが可能になり，大学院程度の学生に対する設計教育 に関して，有益ではないかと思われる。

以上の背景に基づき, 本稿では, 概念設計段階の機体形 状の変化が空力特性に及ぼす影響を，より明確にできる教 育目的の設計法について考える. 弚のために境界要素法7) を用いた空力計算を含んだ航空機概念設計について，本稿 の前半で考えていく. 境界要素法は CFD に比へて計算時 間が短くて済むので, パラメトリック・スタディを行うこと に適している、概念設計段階でVortex Lattice 法 (VLM) を用いることも行われるが，VLM では薄翼近似を用いて いるために，機体形状の定義を正確に行うことができない． これに対して境界要素法プログラムを利用すると，機体形 状を CAD で描画することも可能であり，光のデータは，概 念設計後の各設計段階にも利用できる特徵を有する .ここ で考察する概念設計法について検証するために，本稿の後 半では単発プロペラ機の概念設計を試みる. また従来の方 法による空力特性の推算結果との比較も行う．

\section{2. 境界要素法}

境界要素法は, 微分方程式を Gauss-Green の定理により 境界上の積分方程式に变換して問題を解く方法である. 本 稿では, 文献 8,9) に基づき, 基礎方程式の Laplace 方程 式に直接 Green の定理を適用して積分方程式を導出する Morino らの方法)を使用した .この方法で物体表面およ びWake 表面上での擾乱速度ポテンシャル $\phi$ を末知数とす る積分方程式を導出する .これから一意な解を得るために 次の 4 つの境界条件を与える.

i. 流れは物体表面に沿う

ii. Wake の厚みは無く, 主流に沿う

iii. Wake の上下面で圧力差は無い

iv. 無限遠で $\phi=0$ である

物体表面およびWake 面を四辺形パネルによって積分方程式 の離散化を行い, 連立 1 次方程式に変換する.ただし Wake パネルは物体表面上の Wake 放出線から主流に沿って放出 する.この連立 1 次方程式を解くことで, 各パネルでの速 度ポテンシャル, 圧力係数, 揚力係数 $C_{\mathrm{L}}$, 誘導抵抗係数 $C_{\mathrm{Di}}$, 重心周りのピッチングモーメント係数 $C_{\mathrm{m}}$ を求める ことができる .

\section{3. 機体表現法および全機のパネル化}

概念設計で使用することを考えると，使用する機体表現 法は , 任意の機体形状を表現できるものでなくてはならな い、また，全機をパネル化し，光の座標データを計算に用 いるので, 数式や関数で表現できることも要求される. 本 稿では，文献9)に記された機体定義方法をもとにして，機 体形状を表現することにした .

単発プロペラ機の設計を行うために，この機体のClean 形体（脚なし，フラップなし）について，全機を胴体・主 翼・水平尾翼・垂直尾翼の 4 つに分けてパネル分割を行う. 胴体に関しては, 2 次の B-スプライン曲面 ${ }^{10)}$ を用いて胴

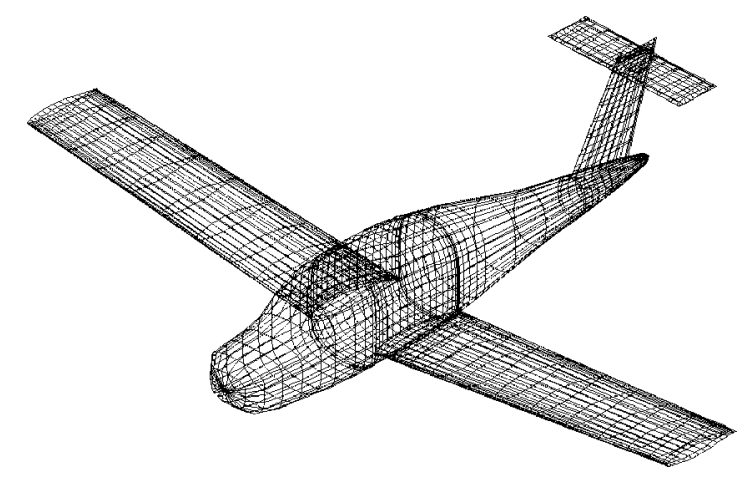

第 1 図 機体のパネル分割例

体の表現を行う . 主流方向に幾つかの初期胴体断面を定め， B-スプライン曲面によって補間することによって，胴体の 周方向と軸方向にパネル分割を行い, 機首エンジン部分や キャノピー部分等の細かい形状変化を有する胴体表現を可 能とした . 第 1 図に機体のパネル分割例を示す. 主翼, 水 平尾翼, 垂直尾翼のコード方向パネル分割数を $w u, h u, v u$, スパン方向分割数を光れぞれ $w v, h v, v v$, 胴体軸方向と周 方向分割数を兴れ光れ $b u, b v$ とすると，これら 8 個の值を 設定することによって，全機がパネル分割される．

ところで胴体も揚力を発生し, Wake 放出面を考える必 要がある，弚こで，ここでは文献9)に従い，主翼の後縁に 続く胴体子午線上に沿って胴体後部までWake 放出線が続 き，この Wake 放出線から主翼翼根部でのコード長の 20 倍 の長さで主流方向に Wake が延びるとした .

次に,パネル分割数と計算精度の関係について考える.境 界要素法では, 主翼・尾翼については, コード方向に細か く，特に前縁付近で細かく分割することで計算精度が向上 することが実証されている ${ }^{11)}$. 乥こで前述の 8 個の胴体パ ラメータを変化させることによって計算に及ぼす影響を調 ベてみた結果, 主翼と尾翼のコード方向分割数が, 計算精度 に大きく影響を与えることが確認された．使用した計算機 のメモリーの制限や計算時間などから勘案して本計算では パネル分割数 $w u=34, w v=16, h u=14, h v=8, v u=$ $7, v v=7, b u=16, b v=12$, 総パネル枚数 1794 枚を計算 に用いることとした .

\section{4. 概 念 設 計 法}

本稿では，境界要素法を用いて空力推算を行いながら， 機体の主要形状パラメータ (主翼アスペクト比 $A R$, 主翼 テーパー比 $\lambda)$ の最適值を求め，機体形状を決定する方法 をとる . 境界要素法では推算することのできない事項につ いては，第 1 章で述べた統計データや光の他の手法を用い ることとする. 補助的に用いるこれら一般的な設計手法に ついては，文献 5,6) を主に参考にする .

本稿で用いる概念設計法として，第 2 図に示す方法を考 えた。まず, 設計要求を明確化するために, 設計する機体 と類似した機体のデータを集めて，データベースを作成す る.次に初期重量推算および Sizing の作業に移る . Sizing 


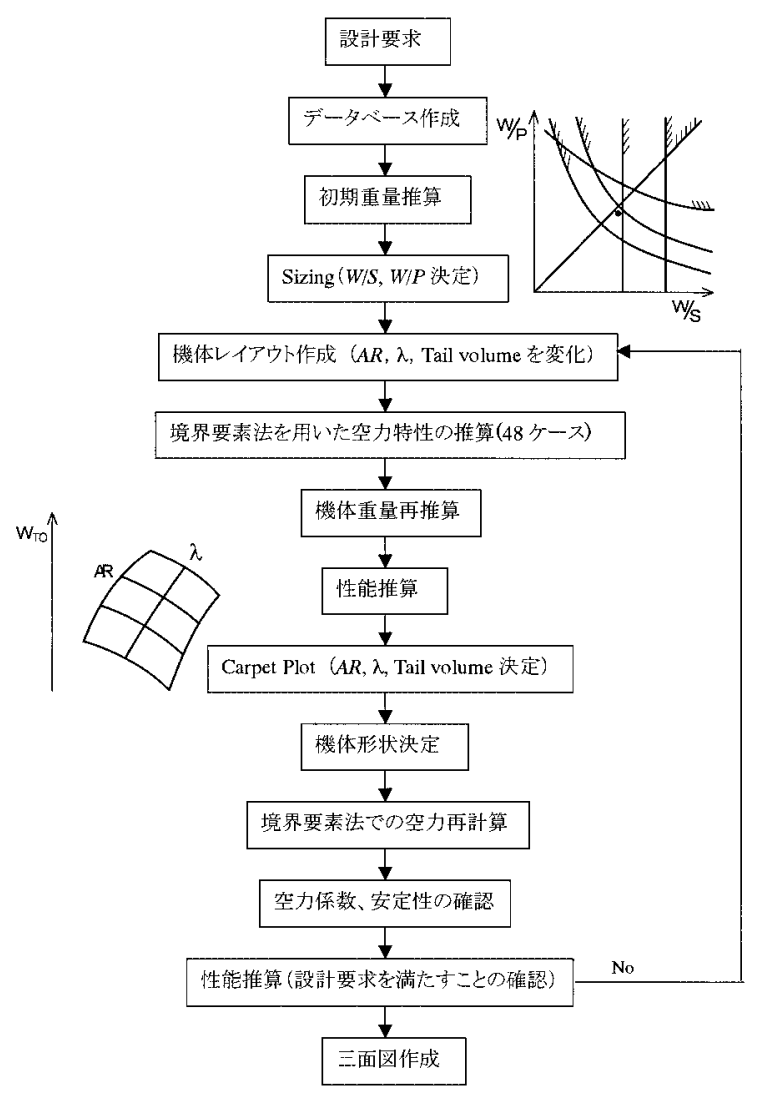

第 2 図 概念設計の流れ

により翼面荷重 $W / S$ および機体重量とエンジンパワーの 比 (Power Loading, $W / P$ ) のベースラインとなる值を定 める、機体レイアウトを考え, 異なる $A R, \lambda$ および尾翼 容積を有する幾通りかの機体形状を設定する．これらの機 体形状について境界要素法に基づく空力計算を行い, 空力 特性や機体安定性の推算值を求める .これらの值をもとに して 2 回目となる全機の重量計算および性能推算を行い， 弚の結果をもとにして, 最大離陸重量を評価值とし $A R$ と $\lambda$ をパラメータとする Carpet Plot を描く.この図を用い て最終機体形状を決定する.最終機体形状に関して空力計 算を再度行った上で性能計算を行い, 帯の結果か設計要求 を満たすことを確認する。

なお本稿では，最大離陸重量を評価値に選んでいる，通 常の設計では直接運航費 (DOC) やライフサイクルコスト (LCC) を評価値として選択することが多い.ただし本稿 で取り扱う機体は単発プロペラ小型機であるため，一般の 輸送機や旅客機とは異なる運用形態である．弚こで機体本 体価格や飛行コスト (燃料費等) に大きく影響すると考え られる最大離陸重量を評価值として選定することとした．

付録 A に，概念設計の個々の手順を詳述する．

$$
\text { 5. 設 計 例 }
$$

第 4 章で述べた航空機概念設計法の検証を行うために， 具体的な機体の設計を行う.

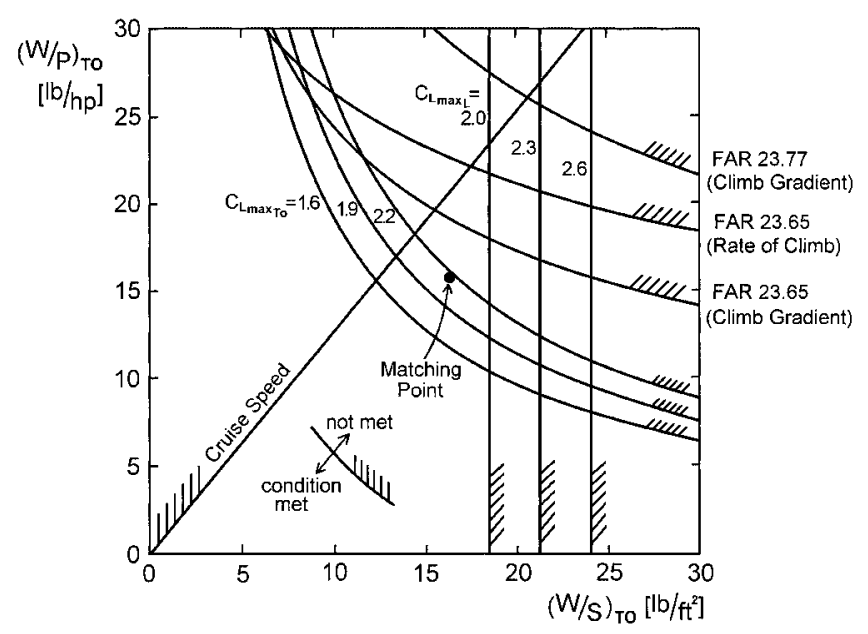

第3図 Sizing 結果 $(A R=8)$

5.1 設計要求 引きこみ脚式の 4 人乗り単発プロペラ 機で, 以下の性能を満たす機体 (全金属構造) の設計を考 える. この要求は PA-28 等の既存の機体の性能を参考にし て決定した .

Range : 520 n.mile

Take-off over $50 \mathrm{ft}: 1600 \mathrm{ft}$

Landing from $50 \mathrm{ft}: 1400 \mathrm{ft}$

Cruise speed : $130 \mathrm{kt}$ at $8000 \mathrm{ft}$

これらの要求以外はFAR23 の規定に従うとする.

5.2 初期重量推算と Sizing 単発プロペラ機の統計 データ ${ }^{12)}$ を用いて 4.1 節の方法で最大離陸重量の初期値 を推算した結果， $W_{\mathrm{TO}}=2830 \mathrm{lb}$ の值が得られた。

主翼アスペクト比 $A R=7,8,9,10$ に関して, 各設計要 求を満たす範囲を求めるための Sizing Diagram を A.1 節 で述べる方法で描いた，乥の一例を $A R=8$ に関して第 3 図に示す。

本設計機体に使用するエンジンとして，類似機体に使用 されることの多い最大馬力 $180 \mathrm{HP} の$ Avco Lycoming O360-A を選択する . エンジン性能として , 文献 13) に示さ れているデータを使用した .このエンジンデータと上で推 算された機体初期重量をもとにして, Sizing Diagram 中の 設計要求を満たす範囲内から，今後の設計のベースライン になる値として

$$
(W / S)_{\mathrm{TO}}=16.3 \mathrm{lbs} / \mathrm{ft}^{2},(W / P)_{\mathrm{TO}}=15.7 \mathrm{lbs} / \mathrm{HP}
$$

を選定した。なお異なる $A R$ の場合でも Sizing Diagram には大きな違いは見られず $A R=8$ の图をもとにしてこれ らの点の選定を行った .これより, 主翼面積 $S$ は $173 \mathrm{ft}^{2}$ となる .

5.3 機体レイアウトの決定 Sizing の結果を用いて，4 人乗りの軽飛行機のレイアウトを作成する . 機体の configurationに関しては一般的な低翼機体とした . またフラップ 使用時の機体トリム変化が小さくなり, 着陸時の操縦を容 易にすると考えられる T-tail 尾翼形状を選択することとし た .この configuration に関して, 胴体・主翼・水平尾翼・ 


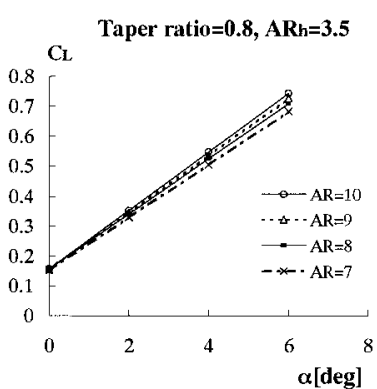

a) 揚力ー迎角曲線(テーパー比一定)

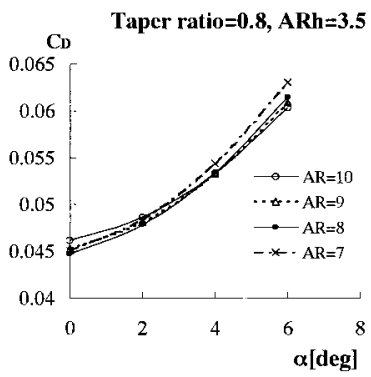

c) 抵抗一迎角曲線(テーパー比一定)

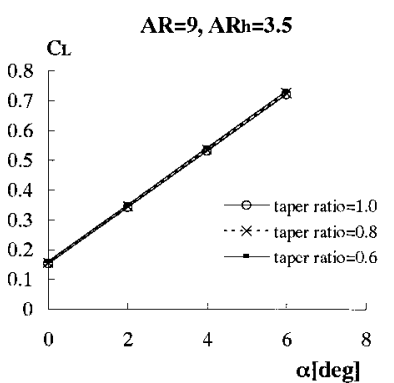

b) 揚カ一迎角曲線(アスペクト比一定)

$A R=9, A R h=3.5$

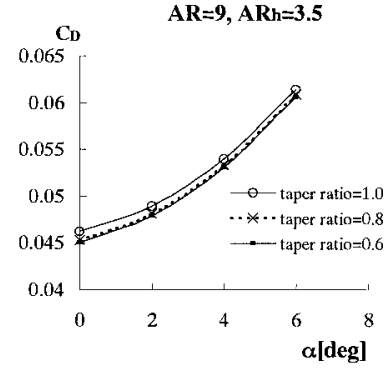

d) 抵抗一迎角曲線(アスペクト比一定)

第 4 図 空力計算結果

垂直尾翼の詳細形状の決定を行う．

5.3.1 胴体 4 人乗りの軽飛行機として妥当な大きさの 胴体を決める . Nose 部分は, エンジンが収納できる大き さにし, Cabin 部分は, 4 人の座席スペースおよび荷物ス ペースを基にして大きさを決めた ${ }^{14)}$.

5.3.2 主翼 主翼面積は Sizing 結果である $S=173 \mathrm{ft}^{2}$ に固定し， $A R$ と $\lambda$ を変化させる. 既存の 4 人乗り単発プ ロペラ機では, $A R$ が 7 8 前後 (複合材料を多用した機体 で 9 前後)， $\lambda$ が $0.7 \sim 1.0$ くらいが一般的な值である. 光 こで, $A R$ を $7,8,9,10$ の 4 通り, $\lambda$ を 0.6, 0.8, 1.0 の 3 通りに变化させて空力計算を行った。

また翼型は層流翼型を採用することとし，既存機の翼厚 比の值を参考にして, 翼根部で $\mathrm{NACA} 63_{3} 218$, 翼端部で NACA $63_{1} 212$ を採用した . 捩り下げ角は $0^{\circ}$ とし，また， 取付角は $0^{\circ}$ として空力計算を行い, 計算結果から巡航時に 必要な取付角度を設けることにした . 上反角は $6^{\circ}$ に固定 した。

5.3 .3 尾翼 本稿では主翼の $A R$ と $\lambda$ の影響を見ること に主眼を置いているため, 安定性に関しては前述した尾翼 容積の検討程度にとどめた .

水平尾翼容積のベースラインとなる値を定めているので (A.2 節参照)，水平尾翼に関しては, 光の值付近で尾翼形 態を変化させた .コード長を $2.2 \mathrm{ft}$, テーパー比を 1.0 に固 定し, 水平尾翼のアスペクト比 $A R_{\mathrm{h}}$ を 3.0 と 3.5 の 2 通 りに変化させた場合の計算を行った . 翼型は NACA0012 を全スパン位置に採用した、なお，T-tail 形態であるため， 水平尾翼の機軸方向位置は垂直尾翼の位置によって定めら れることになる，乥こで，機軸方向に垂直尾翼位置を胴体 長さ方向に 2 通り，すなわち全機重心位置と水平尾翼空力 中心との機軸方向距離 (Tail Arm) $L_{\mathrm{H}}$ を 2 通りに変化さ

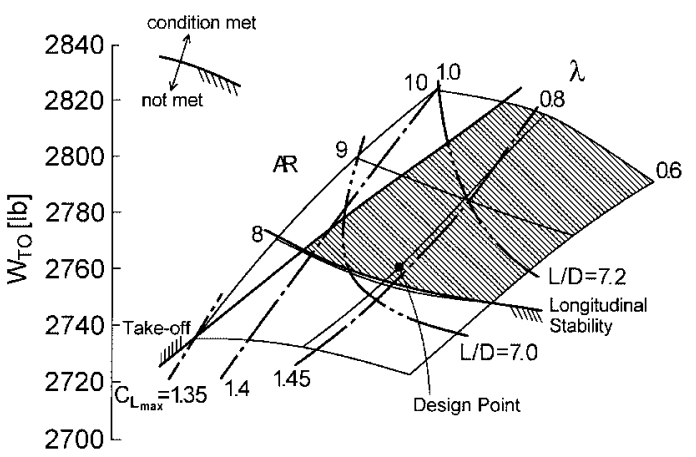

第5図 Carpet Plot

せて計算を行った.$L_{\mathrm{H}}$ は前述の水平尾翼容積のベースラ イン值を中心として変化するように決めた．なお機体重心 位置は A.4 節の方法で推算する位置に基づいて決めた . 結 局, 水平尾翼容積としては 4 通りに変化させて計算を行う ことになった .

横・方向の安定性に関して, 垂直尾翼面積と平面形 (ア スペクト比 3.4 , テーパー比 0.6 , 面積 $S_{\mathrm{V}}=15.7 \mathrm{ft}^{2}$ ) は 固定して一形態のみとした . ただし , A.2 節の垂直尾翼容 積のベースライン值の範囲には含まれていることを確認し た .垂直尾翼の翼型は NACA0012 を全スパン位置に採用 した .

5.3.4 空力計算に用いるレイアウト 以上で決定された 機体レイアウトが第 1 図に示したものである . 上述した各 種パラメータを振ることで, 合計 48 通りのレイアウトに 関して空力計算を行う $\left(A R: 4\right.$ 通り, $\lambda: 3$ 通り, $A R_{\mathrm{h}}: 2$ 通り, $L_{\mathrm{H}}: 2$ 通り).

5.4 空力特性の推算結果 境界要素法によって求まっ た $C_{\mathrm{L}}, C_{\mathrm{Di}}, C_{\mathrm{m}}$ と，A.3 節で説明する方法で求めた $C_{\mathrm{Do}}$ より，機体の空力特性を推算した結果を $A R_{\mathrm{h}}=3.5$ の場 合を例として第 4 図に示す. 48 通りの機体レイアウトに 関して計算を行った結果のうち, テーパー比が一定の場合 $(\lambda=0.8)$ とアスペクト比が一定の場合 $(A R=9)$ に関 する揚力曲線と抗力曲線である. 图によると, テーパー比 が一定では，アスペクト比が大きいほど揚力傾斜が大きい こと（第 4 図a）が読みとれる．また，アスペクト比がー 定では, 計算した範囲では, テーパー比が小さいほど，抵 抗が小さい値となることが読みとれる (第 4 图 d).

5.5 Carpet Plot の結果 A.4 節の重量再計算と A.5 節の性能計算方法を用いて Carpet Plot を作成する.空力 計算を行った結果から，縦の安定性がより高い Tail Arm の值と $A R_{\mathrm{h}}$ の值 $(=3.5)$ を選定することとした (A.3 節 参照) .この場合について Carpet Plotを描いた結果を第 5 図に示す.

Carpet Plot を描くときに検討した設計要求は, 離陸距 離, 着陸距離, 航続距離, 巡航速度である.ただし着陸距 離, 航続距離, 巡航速度に関しては, 検討を行ったすべて の機体に関して設計要求を満たしていた .これは 5.2 節で 行った Sizing において, 荒い推算ではあるものの設計要求 を満たす一点を選択し，乥れに関して $A R$ と $\lambda$ を振るこ とによって機体形状を変化させたためであると考えられる． 
第 1 表 最終性能計算結果

\begin{tabular}{lcc}
\hline & Requirement & Present Results \\
\hline Passenger & 4 & 4 \\
Engine & - & O-360-A $180 \mathrm{HP}$ \\
Empty weight $W_{\mathrm{E}}(\mathrm{lb})$ & - & 1550 \\
Max. T/O weight $W_{\mathrm{TO}}(\mathrm{lb})$ & - & 2760 \\
$(W / S)_{\mathrm{TO}}\left(\mathrm{lb} / \mathrm{ft}^{2}\right)$ & - & 16.3 \\
$(W / P)_{\mathrm{TO}}(\mathrm{lb} / \mathrm{HP})$ & - & 15.7 \\
Wing area $S\left(\mathrm{ft}^{2}\right)$ & - & 173 \\
Aspect ratio $A R$ & - & 8.2 \\
Taper ratio $\lambda$ & - & 0.8 \\
Dihedral angle $\Gamma(\mathrm{deg})$ & - & 6 \\
Span length $b(\mathrm{ft})$ & - & 37.7 \\
Overall length $(\mathrm{ft})$ & - & 25 \\
T/O field length $(\mathrm{ft})$ & 1600 & 1590 \\
Landing field length $(\mathrm{ft})$ & 1400 & 1290 \\
Rate of climb at sea level (ft/min) & - & 1090 \\
Cruise speed at $8000 \mathrm{ft}(\mathrm{kt})$ & 130 & 132 \\
Stall speed at landing config. $(\mathrm{kt})$ & - & 49 \\
Range (n.mile) & 520 & 520 \\
\hline
\end{tabular}

離陸距離についてはここで検討した $A R$ と $\lambda$ の組み合わせ の中で設計要求を満たさない場合があったので, 弚の範囲 を Carpet Plot 上に記入した . また今回考慮に入れた機体 レイアウトの組み合わせの中には縦の静安定 (A.3 節) の 条件を満たさない場合もあり，弚の範囲を図中に記入した . 更には, 最終機体形状の設計点選択の一助となるように最 大揚力係数 $C_{\mathrm{Lmax}}$ と全機揚抗比 $L / D$ も第 5 図に記入し た . 図の斜線の部分が, 設計要求を満たす範囲である .

この図より主翼アスペクト比 $A R$ が小さいほど，また テーパー比 $\lambda$ が小さいほど, 機体重量が減少することがわ かる．アスペクト比か増大すると $L / D$ が向上するために 巡航に必要な燃料重量は低下するが, 主翼の構造重量が増 大するために機体重量の増大を招いたと考えられる . また テーパー比を適度な值に選択することは, 空力的には性能 向上 ( $L / D$ 向上), 構造的には重量軽減の方向に働くこと が読みとれる。

第 5 図から設計点を選択するために , ここでは以下の条 件を用いた。

・設計要求を満たすこと (Carpet Plot の斜線部分)，

・翼端失速を避けるために， $\lambda$ を小さくしすぎない，

・失速速度を下げるために $C_{\mathrm{Lmax}}$ がなるべく大きいこと，

・機体総重量か軽いこと,

以上の諸点を考慮に入れて, $A R=8.2, \lambda=0.8, A R_{\mathrm{h}}=$ 3.5 を設計点として選択することとした .

5.6 最終結果 $\quad A R=8.2, \lambda=0.8, A R_{\mathrm{h}}=3.5$ の形 状に関して，再び境界要素法による空力計算を行った .こ の形態について性能計算を行った結果を第 1 表に示す．第 1 表によると，設計した機体性能については，すべての設 計要求を満たしていることがわかる.

最後に, 境界要素法プログラムのパネルデータを利用し て機体形状を描き，脚配置などを考慮して图面に修正を加 えた .この結果 (機体三面図) を第 6 図に示す．
6. 考察

6.1 本設計法の制限事項 本稿では, 限られた教育力 リキュラムの時間制限内で, 概念設計段階の機体形状変化 が空力特性に及ぼす影響を，より明確にできる教育目的の 設計法を目指している．とのために従来からの航空機概念 設計法と境界要素法による空力計算を組み合わせることで， 単発プロペラ機の設計を試みてきた．本章では，本稿で用 いた設計方法の問題点, 制限事項等について検討を行う.

・重量推算法 : A.1 節と A.4 節で説明されているように 2 段階に分けて重量推算を行った . 最終機体形状を決定す るにあたって, $A R$ 変化等の影響を見るために主翼に関し てのみ比較的詳細な重量推算を行った．ただし，他の部分 に関しては非常に荒い推算にとどまっている．また，主翼 の形状変化に応じて翼胴結合部の必要強度か変化し胴体重 量が変化することや，T-tail のため垂直尾翼の強度増強が 必要となり尾翼重量か増大することが考えられるが，これ らの点は考慮されていない．重量推算精度向上のためには 例えば文献 15,16$)$ 等の機体コンポーネント別重量推算法 を適用する必要がある。

・Sizing 方法 : 本稿では機体形状が機体空力特性に及ぼ す影響を見るために 2 個のパラメータ $(A R, \lambda)$ を用いて Sizing を行った .このため, 主翼面積 $S$ については第一段 階の Sizing で決定した值に固定して使用した . 主翼断面形 状, 尾翼関係のパラメータ等, 機体特性に影響を及ぼすパ ラメータとしては他にも多数あるが, これらのパラメータ に関する検討は不十分なままである . なお Carpet Plot を 用いる場合には，2 個より多い設計パラメータを同時に最 適化することには困難を伴う .この点を改善するためには， Carpet Plot の代わりに多変数の同時最適化が可能な他の 手法の活用が必要である.

- 空力特性 : 境界要素法の制約のために最大揚力係数の見 


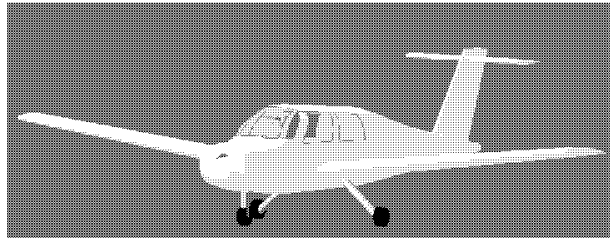

a）機体鳥瞰図（脚付き）
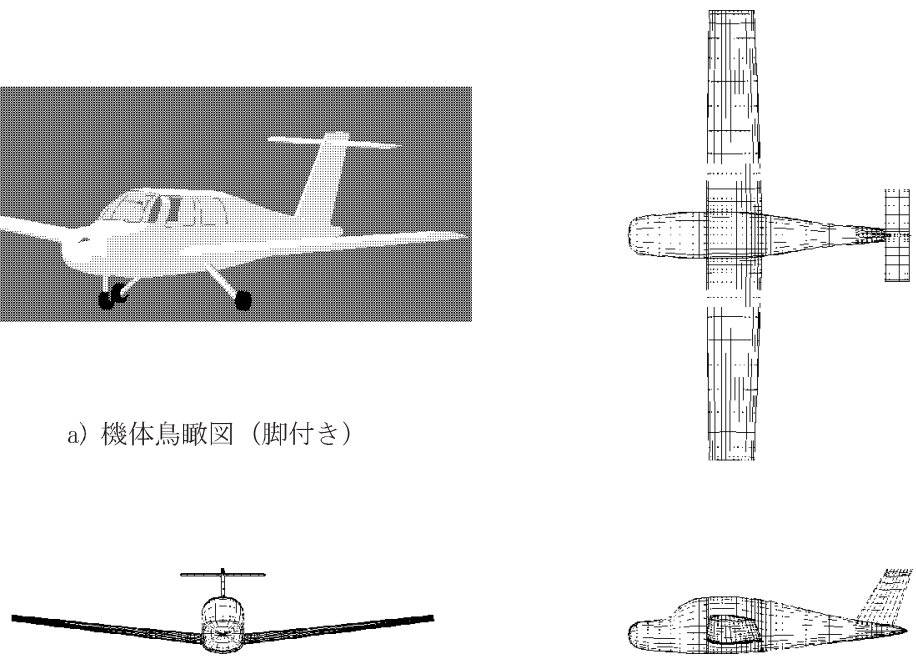

b) 機体三面図（脚なし）

第 6 図 最終機体形状図

積もりは従来から用いられてきた統計的方法に頼らざるを 得なかった . プロペラの後流の影響については, 空力推算 では全く考慮に入れられていない . プロペラの影響を考慮 に入れた推算法 ${ }^{17)}$ の活用を考える必要がある. 主翼後方に 発生する Wake に関しては, 主流に沿った平面的な形態を 考えていたが，Wake を流線に沿って分布させる方法8)を 用いることも検討する必要がある。

・安定性 : 本稿では主翼 $A R$ と $\lambda$ の変化の影響を調べる ことに主眼をおいたため, 安定性の検討は簡便な方法にと どまった . 縦の静安定については, 多少の検討を行ってい るが, 横・方向の安定性については尾翼容積以外ここでは 考慮に入れられていない. 空力特性の推算と並行して安定 性の確認を行うことが必要である

本稿で用いた設計法にはこれらの点以外にも, 主翼の構 造強度推算を行うこと等，改良する余地がある.ただし， $A R や \lambda$ といった主要空力パラメータの変化がどのように 影響を及ぼすかを見ながら概念設計を行う点は可能になっ たと考えられる．また，境界要素法プログラムでのパネル 頂点座標のデータを利用することで，CAD ソフトウェア を利用して，機体形状を容易に描画することができる。こ のため CAD によって機体形状を確認しながら，概念設計 および空力計算を進めていくことが可能である．なお，本 稿では conventional な機体レイアウトのみを考えたが , 先 尾翼形態機のような自由な機体レイアウトの配置が可能に なる設計法について考えることも興味深い .

6.2 従来の設計法との比較 本節では, 統計データに 基づく空力特性推算法と境界要素法との比較を行う．比較 の対象は, 第 4 図に示した主翼アスペクト比 $A R$ を変化さ せた機体 $\left(\lambda=0.8, A R_{\mathrm{h}}=3.5\right)$ である. Roskam ${ }^{18)}$ に 示されている DATCOM に基づく空力特性推算方法を用い て, 機体の揚力係数 $C_{\mathrm{L}}$ と摩擦抵抗等を除外した揚力依存 抵抗係数 $C_{\mathrm{DL}}$ を推算した (第 7 図 b), d) ). 第 7 図 a), c) には境界要素法 (BEM) の結果を示す.これらを比較 すると ARの増大に伴い Roskam と BEM 共に同程度の揚
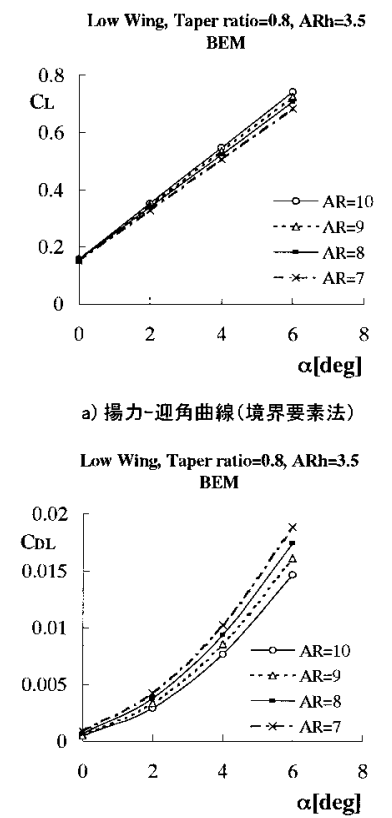

c) 揚力依存抵抗一迎角曲線(境界要素法)

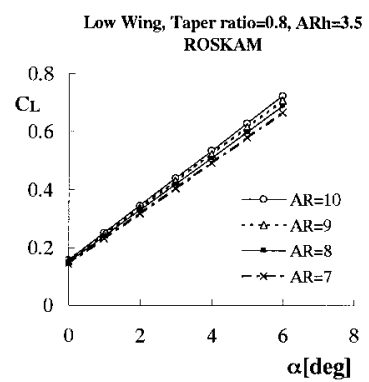

b) 揚力-迎角曲線 (ROSKAM)

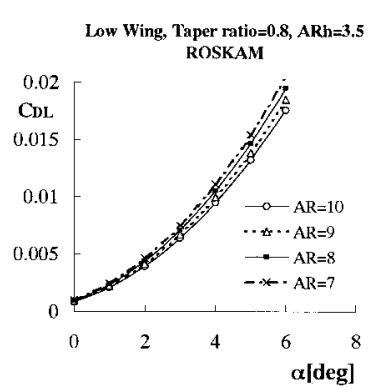

d) 揚力依存抵抗-迎角曲線(ROSKAM)

第 7 図 従来法との比較 ( $A R$ の影響)

力傾斜の増大や抵抗の減少が見られる. また各係数の值も ほぼ同程度である．ARの変化に関して，従来の方法でも BEM と同樣な空力特性の推算が可能なことを示している . ただし第 1 章でも述べたように，理論に基づいた BEM で は計算結果を吟味することにより，光の物理的意味を学生 が把握することは比較的容易であると考えられる．

次に主翼上下位置の違いについて考える．本稿では，低 翼機の設計について検討してきたが, 機体パネル分割の際 に主翼位置を上方へ移動することで高翼機の機体形状に変 更できる.主翼位置を胴体上部に取り付けた高翼機（低翼 機の主翼位置から上方へ胴体長の $11.5 \%$ 移動させた, 上反 角は $\left.0^{\circ}\right)$ について空力特性を推算した $(A R=9, \lambda=0.8$, $A R_{\mathrm{h}}=3.5$, 第 8 図). BEM の結果 (第 8 図 a ), c) ) に 


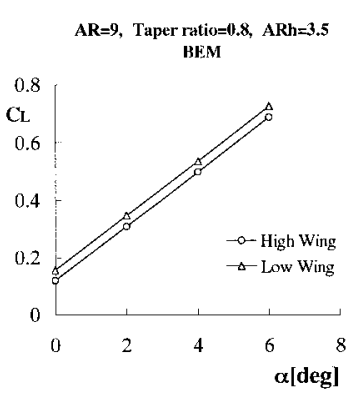

a) 揚力-迎角曲線(境界要素法)

$\mathrm{AR}=9$,
Baper ratio=0.8,
$\mathrm{BRh}=3.5$

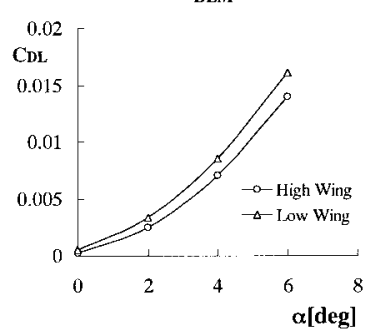

c) 揚力依存抵抗一迎角曲線(境界要素法)

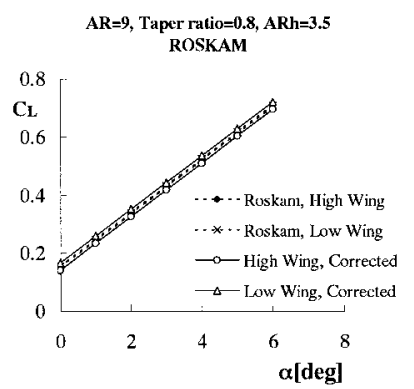

b) 揚力一迎角曲線(ROSKAM) $\mathrm{AR}=9$, Taper ratio=0.8, $\mathrm{ARh}=3.5$

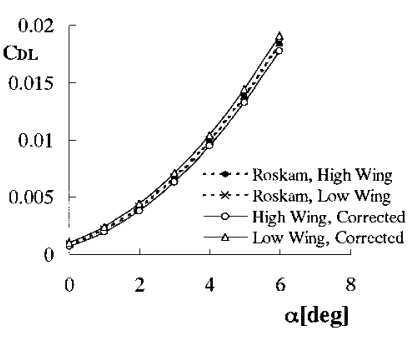

d) 揚力依存抵抗-迎角曲線 (ROSKAM)

第 8 図 従来法との比較 (主翼上下位置の影響)

よると低翼機は高翼機に比べて揚力と抵抗が大きい，翼上 面と胴体との干渉により流れか加速され揚力が増大するた めである (翼面上圧力分布を比較することで読みとれる) . Roskam の結果 (第 8 図 b) ,d) の点線) では, 高翼と低翼 で両者にほとんど違いが見られない，文献 18) では尾翼へ の吹下しにのみ主翼位置を考慮し, 胴体と主翼の干渉につ いて考慮されていないためである. Roskam の方法に加え て付録 A. 3 に示す主翼の上下位置の差による揚力係数変化 $\left(\Delta C_{\mathrm{L} 1}\right)$ を考慮に入れた(第 8 図 b)，d）の実線）。この 補正を行うと BEM と同樣な変化の傾向が見られる.しか しこの補正に伴う揚力の差は BEM の結果より若干小さい .

以上のことより, 従来法 (統計データベース) でも, 適 切な推算法を付加することで空力特性の推算は可能である ことがわかる.すなわち過去の経験が十分に蓄積された設 計現場において，従来法が用い続けられていることに支障 はない，しかし，本節の主翼上下位置の補正に見られたよ うに，任意の形状を有する機体ごとに必要な補正法を適宜 付加して空力特性を推算する必要がある.このため経験の 少ない学生による設計では, 詳細な指導が必須となる .こ れに対して,BEM では機体形状変化の空力特性への影響 を適切に推算するため, また経験式を単に付加する方法に 比へてて物理的意味をより理解しやすいため，学生による機 体設計に際して本方法は十分有用であると考えられる .

なお, 翼単独での $A R や \lambda の$ 変化が空力特性に及ぼす影 響は, 古典的な翼理論でも推算可能である. 学部レベルの 教育においては，このような翼理論の教育が行われている . 一方，本稿の設計教育の一つの主眼は，翼理論等の個別の 知識を有した学生が機体全体の設計を行う際に，光れらが どのように複合的に組み合わさっているかを理解させるこ とにある

7. 結 論

大学等における航空機設計教育において従来から用いら れている航空機概念設計法では, 初めて設計を行う学生が, 航空機の空気力学的パラメータ (アスペクト比 $A R$, テー パー比 $\lambda$ 等) の変化か設計結果にどのような影響を及ぼす か理解することに，しばしば困難を伴っていた . 本稿では， 従来の統計データを多用した概念設計法に境界要素法によ る空力計算を融合させた単発プロペラ機の教育用航空機設 計法について考えた、設計の第一段階として Sizing を行い 機体レイアウトの概略を決めた上で，次に空力計算結果に 基づいて $A R$ と $\lambda$ の影響を見るための Carpet Plot を作 図し、設計機体を決定する方法である. 光の結果，以下の 結論が得られた .

1. 機体の空力特性に大きな影響を与える主翼の $A R$ と $\lambda$ について，統計データのみに頼るのではなく，空力計算 の結果も含めることで，できるだけ最良な值を概念設計段 階で選定することが可能になり，弚のときの空力特性，全 機性能, 機体重量に及ぼす影響を設計者 (学生) が把握で きる。

2. 境界要素法を用いることで，一般的な機体形状には 限られるが，ある程度は自由に形状変化を考慮しながら概 念設計を行うことができる.設計者 (学生) の意向が反映 されるレイアウトに関して，機体の空力特性ならびに弚の 物理的意味を把握しながら設計を進めていくことが可能で ある

3. 従来法 (統計データベース) と境界要素法との空力特 性推算の比較を行った . 従来法では, 機体形状に応じて補 正式を付加することが必要であるのに対して, 境界要素法 では経験の少ない学生でも適切な推算が可能である .

本研究で使用した境界要素法プログラムは, 佐藤淳造東 京大学名誉教授, 元東京大学大学院生の杉本 晃氏と松本 茂雄氏が作成された計算プログラムに基づいている．ここ に感謝の意を表する。

\section{参 考 文 献}

1) Torenbeek, E.: Synthesis of Subsonic Airplane Design, Delft University Press, Delft, 1976, pp. 1-26.

2) Breuhaus, R. S., Fowler, K. R. and Zanatta, J. J.: Innovative Aspects of the Boeing 777 Development Program, Proc. 20th Cong. Int. Council Aero. Sci., ICAS-96-0-4, 1996, pp. LXV-LXXXVII.

3) Hoak, D. E., Finck, R. D., Ellison, D. E. and Maltman, L. V.: USAF Stability and Control Datcom (Data Compendium), Air Force Flight Dynamics Lab., Wright-Patterson AFB, Ohio, 1960.

4) Engineering Sciences Data Unit: ESDU Engineering Sciences Data, ESDU International plc, London, 1981.

5) Roskam, J.: Airplane Design, Part I-VIII, University of Kansas, Kansas, 1985.

6) Raymer, D. P.: Aircraft Design: A Conceptual Approach, 2nd Ed., AIAA, Washington, 1992.

7) Morino, L., Chen, L. T. and Suciu, E. O.: Steady and Oscillatory Subsonic and Supersonic Aerodynamics around Complex Configurations, AIAA J., 13 (1975), pp. 368-374. 
8) 杉本 晃, 佐藤淳造 : 誘導抵抗を減少させる三次元翼平面形状に ついて，日本航空宇宙学会誌，40 (1992), pp. 603-609.

9) 松本茂雄, 佐藤淳造 : 境界要素法を用いた航空機胴体形状の最適空 力設計について, 日本航空宇宙学会誌，41 (1993), pp. 712-720.

10) 桜井 明 : スプライン関数, 東京電機大学出版局, 東京, 1981.

11）柳沢三憲 : 境界要素法を用いた亜音速流における三次元揚力物体 に働く定常および非定常空力特性に関する研究, 東京大学学位請 求論文, 1985 .

12) 文献 5), Part I: Preliminary Sizing of Airplanes, pp. 5-196.

13) McCormick, B. W.: Aerodynamics, Aeronautics and Flight Mechanics, John Wiley \& Sons, New York, 1979, pp. 336337.

14) 文献 5), Part III: Layout Design of Cockpit, Fuselage, Wing and Empennage: Cutaways and Inboard Profiles, pp. 85-122.

15）文献 6), pp. 399-407.

16) 文献 5), Part V: Component Weight Estimation.

17) Veldhuis, L. L. M. and Henyma, P. M.: Aerodynamic Optimisation of Wings in Multi-Engined Tractor Propeller Arrangements, Aircraft Design, 3 (2000), pp. 129-149.

18) 文献 5), Part VI: Preliminary Calculation of Aerodynamic, Thrust and Power Characteristics , pp. 21-116, 213-354.

19) 文献 6), pp. 110-113.

20) 文献 6), pp. 220-221, 325-331.

21) 文献 5), Part II: Preliminary Configuration Design and Integration of the Propulsion System, pp. 107-122.

22) 文献 6), pp. 280-290, 330-331.

23) 文献 1), pp. 477-479.

24) 文献 5), Part VI, Preliminary Calculation of Aerodynamic, Thrust and Power Characteristics, pp. 245-276.

25) 文献 6), p. 418.

26) 文献 6), pp. 395-399.

27) 文献 6), p. 404

28) 文献 1), p. 167

29) Ojha, S. K.: Flight Performance of Aircraft, AIAA, Washington, 1995 , pp. 377-379, 384-388.

30) 文献 28), pp. 379-380, 389-392.

31) 文献 5), Part VII: Determination of Stability, Control and Performance Characteristics: FAR and Military Requirements, pp. 124-130.

32) 文献 6), pp. 525-532.

33) 文献 6), pp. 232-236.

\section{付録 $\mathrm{A}$ 概念設計手順の詳細}

A.1 初期重量推算と Sizing Sizing においては, 境界 要素法による推算を行うためのべースラインとなる離陸時 の翼面荷重 $(W / S)_{\mathrm{TO}}$ と Power Loading $(W / P)_{\mathrm{TO}}$ の値 を知っている必要がある .これらの值を求めるために, 以 下に示す文献 12) の方法を用いた . まず，初期重量推算を 行う.この推算は, 要求された航続距離から飛行に必要な 燃料重量を求め, 統計データから見積もった最大離陸重量 $W_{\mathrm{TO}}$ と空虚重量 $W_{\mathrm{E}}$ の関係式を当てはめることによって， $W_{\mathrm{TO}}$ を見積もる方法である．

引き続いて, 各設計要求 (離陸距離, 着陸距離等) や FAR23 に規定される上昇率と上昇勾配を満たす $(W / S)_{\mathrm{TO}}$ と $(W / P)_{\text {TO }}$ の関係 (Sizing Diagram) をグラフに描いて (第 2 図上部のグラフ参照), 設計点として適当と思われる $(W / S)_{\mathrm{TO}}$ と $(W / P)_{\mathrm{TO}}$ の值を決定する. この結果と初期 重量推算結果から, 主翼面積 $S$ と離陸時のエンジンパワー $P_{\mathrm{TO}}$ のベースラインとなる值を決定できる . あるいは , あ らかじめ既存のエンジン特性データから, 設計機体に使用 するエンジンを選択しておいた上で $(W / S)_{\mathrm{TO}}$ すなわち主 翼面積 $S$ を決定する手順をとる .
A.2 機体レイアウトの決定 次に, 設計要求に近い機 体データなどを基にして，ある程度の形状の目安を付けた 上で, 主翼のアスペクト比・テーパー比・上反角・翼根部 と翼端部の翼型・主翼取り付け位置, 尾翼のアスペクト比・ テーパー比, 垂直尾翼と水平尾翼の尾翼容積, 胴体形状な どを変化させて, 数通りのレイアウトを作成する.なお，垂 直尾翼と水平尾翼の尾翼容積については, 文献 19)て設計 初期段階に推奖されている值をべースラインの值とする.

プロペラ諸元については, プロペラ効率 $\eta_{\mathrm{p}}$ 等を文献 20) に示された方法で推算する .この他 , 胴体やキャビンの大 きさなどは, 要求されたペイロードとエンジンの収容を考 慮に入れて, 文献 21）を参考にして形状を考える. 境界要 素法プログラムを用いて機体のパネル分割を行った結果と 市販三次元 CAD ソフトを利用することで , 機体形状の描 画を行う・よって，CAD によって機体形状を確認しながら 機体レイアウトの設計を進めて行くことができる .

A.3 空力特性の推算 機体レイアウトか完成すると，作 成されたレイアウトすべてについて境界要素法による計算 を行い, 揚力係数・誘導抵抗係数・ピッチングモーメント 係数を求める. 境界要素法では求めることのできない摩擦 抵抗係数 $C_{\mathrm{D} 0}$ については, 文献 22$)$ に従い, 胴体・主翼・ 水平尾翼・垂直尾翼・エンジン・コックピットの 6 つの部 分に分けて, 各部分の表面積と摩擦抵抗係数を掛け合わせ, 弚れらの摩擦抵抗を推算し足し合わせることで, 全機の摩 擦抵抗を求める.

境界要素法では，粘性の影響を考慮していない，弚のた め, 揚力係数は迎角に対して線形的に変化し，離着陸性能 を推算するために必要な最大揚力係数 $C_{\mathrm{Lmax}}$ を求めること はできない，光こで以下に示す経験的方法によって $C_{\mathrm{Lmax}}$ の推算を行うこととした．すなわち主翼単体に関しては， DATCOM の方法 ${ }^{3)}$ で主翼単体の最大揚力係数 $C_{\text {Lmaxw }}$ を 推算する . 次に, 主翼の上下位置の違いによる揚力係数の 変化 $\Delta C_{\mathrm{L} 1}$ を文献 23) の方法で考慮に入れ, 文献 24) の方 法で尾翼への Down Wash の影響 $\Delta C_{\mathrm{L} 2}$ を考慮して，こ れら $\left(C_{\mathrm{Lmaxw}}, \Delta C_{\mathrm{L} 1}, \Delta C_{\mathrm{L} 2}\right)$ の和をとることで全機の $C_{\text {Lmax }}$ を推算する .

次に，設計された機体の安定性について検討を行う．本 稿では以下に示す簡易的手段を用いる．重量・重心の推算 結果と境界要素法の結果から迎角に対するピッチングモー メントの勾配 $C_{\mathrm{m} \alpha}$ が求まるので, 文献 25$)$ に示された代 表的な $C_{\mathrm{m} \alpha}$ の值 (軽飛行機の場合 $C_{\mathrm{m} \alpha}<-0.65$ ) と比 較することによって重心位置と全機空力中心の位置関係お よび縦の安定性の確認を行うこととした .この段階で縦の 静安定の余裕が極端に少ないときには主翼取り付け位置等 の機体レイアウトを大きく見直すことになる．

A.4 機体重量の再推算 次に, 作成したレイアウトの すべてについて, 機体重量の再推算を行う.ある程度の形 状が決まっているので, 文献 26) の「グループ別重量推算」 方法に従って, 機体を大きく 9 つのグループ (主翼, 水平 尾翼，垂直尾翼，胴体，脚，エンジン，燃料，ペイロード， 弚の他) に分けて, 㫕れグループ別の重量を推算す 
る.この方法は，機体の幾何形状の概略 (ぬれ面積等) が 決まれば, 機体重量と重心位置の推算がある程度までは可 能な方法である. 機体重量の中で $A R$ と $\lambda$ の影響を大き く受ける主翼の構造重量については文献 27) で与えられて いる重量推算式を用いてできるだけ詳しく推算する．この 式は, 主翼の $A R, \lambda, S$, 主翼最大厚み比, 最大離陸重量 $W_{\mathrm{TO}}$ をパラメータとして主翼重量を推算する式である. ま た，ここで推算し直した機体空虚重量 $W_{\mathrm{E}}$ と空力計算よ り求められた巡航時の揚抗比 $(L / D)_{\text {cr }}$ を, Breguet の航続 距離式 (例えば文献 5 ) 参照) に適用することによって，設 計要求中の航続距離を実現する燃料重量を推算し，これに $W_{\mathrm{E}}$ とペイロード重量を足し合わせて $W_{\mathrm{TO}}$ を求める . こ れによって, 最大離陸重量についても $A R$ と $\lambda$ による影響 が加味されていることになる.ここでの結果が初期重量推 算結果と極端に異なる場合には，機体レイアウトを作成し 直す.

A.5 性能計算および Carpet Plot 次にこれらの空 力計算結果等を用いて, 各機体レイアウトに関する性能推 算を行い，Carpet Plot を作成する作業へと移る，性能推 算としては, 離陸距離 (Take-off Field Length), 着陸距 離 (Landing Field Length), 上昇率, 上昇勾配, 巡航速度 に関して検討する。離陸距離は離陸を Ground Run , Rotation，Lift-off，50 ft までの Climbの 4 段階に分割して ,
文献 28）と 29）の方法て離陸距離を推算する . 着陸距離は 着陸を $50 \mathrm{ft}$ からの Approach , Flare , Rotation , Ground Run の 4 段階に分割して, 文献 30) の方法で着陸距離を 推算する.上昇性能は, 文献 31)の方法で上昇率等を推算 する . 巡航性能は, 巡航高度において利用パワーと必要パ ワーが等しいとして巡航速度を算出する．

Carpet Plot では, $A R$ と $\lambda$ をパラメータにとり，最大 離陸重量を評価值とした図を描く (第 2 図参照). Carpet Plot の作成は文献 32) に示された方法を用いる．ただし文 献 32) では $W / S$ と $W / P$ をパラメータにとり，各性能を 整理しているが, ここでは $A R$ と $\lambda$ をパラメータとして Carpet Plot を描く. 描いた图をもとにして機体の設計点 を選択する、設計点の選択方法については設計具体例を示 す 5.5 節において述べる.

以上の方法で決定された機体形状に関して再度, 境界要 素法による空力計算を行い, 性能計算を行う．もし，光の 結果か設計要求を満たさない場合には, Carpet Plotによ る設計点を変更したり，あるいはレイアウトを作成し直す などして, 設計要求を満たすまで, 作業を繰り返す.最後 に脚配置および車輪の選択 ${ }^{33)}$ を行い, 機体重心位置との兼 ね合いを考えながら CAD 上の機体图面において脚を機体 に付け加える作業を行う. 